\title{
Genome and chromosome disposition at somatic metaphase in a Hordeum $\times$ Psathyrostachys hybrid
}

\author{
IB LINDE-LAURSEN \& JENS JENSEN \\ Plant Biology Section, Risø National Laboratory, DK-4000 Roskilde, Denmark
}

\begin{abstract}
The distribution of chromosomes by centromeres and telomeres was studied in 100 squashed, somatic metaphases of a Hordeum vulgare $(2 n=2 x=14) \times$ Psathyrostachys fragilis $(2 n=2 x=14)$ hybrid. The chromosomes and chromosome arms were individually identified in each of the parental genomes by their Giemsa C-banding patterns. The $P$. fragilis chromosomes were more widely scattered on the metaphase plate, and were therefore, also, on average located further from the cell centre than the $H$. vulgare chromosomes. Within the parental genomes, the only exception from a random distribution of the chromosomes was that the two satellited chromosomes of $H$. vulgare were located closer to each other and to the cell centre than can be attributed to chance. This association was most clearly expressed for the telomeres of the chromosome arms carrying the satellites. The data suggest that the parental chromosome complements constitute separate units. This was supported by the observation that five cells had their genomes arranged side-by-side.
\end{abstract}

Keywords: barley, cell, chromosome distribution, intergeneric hybrid, metaphase.

\section{Introduction}

We have previously studied the arrangement of genomes and chromosomes in squashed, somatic metaphases of interspecific hybrids of Hordeum vulgare $(2 x)$ and the polyploid species, $H$. jubatum $(4 x), H$. brachyantherum $(4 x)$ [called $H$. roshevitzii $(4 x)$ ], $H$. brevisubulatum ssp. turkestanicum $(6 x)$, and Triticum aestivum $(6 x)$ (Linde-Laursen \& Jensen, 1984). The chromosomes were identified by Giemsa C-banding. The genomes were disposed with that of $H$. vulgare on average closest to the metaphase centre. This agrees with observations of squashed and serial-sectioned metaphases of interspecific and intergeneric hybrids in the light and electron microscopes, respectively, e.g. by: Finch et al. (1981), Finch \& Bennett (1981, 1983), Finch (1983), Bennett (1984a), Linde-Laursen \& Bothmer (1984), Schwarzacher et al. (1984) and Schwarzacher-Robinson et al. (1987). Gleba et al. (1987) observed a similar separation of the parental genomes in somatic cell hybrids of Nicotiana chinensis + Atropa belladonna and Nicotiana plumbaginifolia + Nicotiana sylvestris. A closer assemblage of the chromosomes of parental genomes resulting in genome separation has been observed or suggested, e.g. in hamster-human cell hybrids (Zelesco \& Graves, 1988). A specific order of the chromosomes within the genome of $H$. vulgare, as reported by Bennett (1982, 1983, 1984a) and Heslop-Harrison \& Bennett (1983a,b, 1984), was not found by us (Linde-Laursen \& Jensen, 1984). In addition, the validity of the finding and its theoretical and statistical bases have been questioned (Coates \& Smith, 1984; Callow, 1985; John et al., 1985; Dorninger \& Timischl, 1987; Rawlins \& Shaw, 1988).

One cause of our failure to observe an ordered arrangement of the chromosomes within the genome may have been the rather limited material studied, only 38 cells, and the use of polyploids as one parent in the hybrids. Bennett and co-workers used diploids exclusively (loc. cit.)

This paper presents results obtained with extensive material from the dipioid hybrid $H$. vulgare $\times$ Psathyrostachys fragilis. The previously applied technique was used, except that the positions of telomeres in addition to the positions of centromeres, relative to the cell centre and to each other (Linde-Laursen \& Jensen, 1984), were studied.

\section{Materials and methods}

The material consisted of 100 euploid, squashed roottip metaphase plates of cloned plants of HH1432-3e [the intergeneric hybrid Hordeum vulgare L. line ' $\mathrm{HP}$ 
40' $(2 n=2 x=14) \times$ Psathyrostachys fragilis (Boiss.) Nevski H $917(2 n=2 x=14)]$. The hybrid, which shows more or less complete uniparental chromosome elimination in some cells, has been studied previously by Bothmer et al. (1984) and Linde-Laursen \& Bothmer (1984). The metaphases were unselected except that (i) only cells with 14 chromosomes, seven from $H$. vulgare and seven from $P$. fragilis, were used; (ii) the chromosomes should be well spread, and in one focal plane; (iii) all chromosomes and chromosome arms of both parental species should be identifiable; and (iv) centromeres, nucleolar constrictions, and telomeres should be clearly discernible.

Cytological identification of chromosomes and chromosome arms was performed using Giemsa C-banding as previously described (Linde-Laursen \& Bothmer, 1984). In text, tables, and figures the $H$. vulgare chromosomes are numbered 1-7 and the $P$. fragilis chromosomes lettered $A-G$ in agreement with conventional use (cf. Linde-Laursen \& Bothmer, 1984). However, to record the positions of the chromosomes in a cell and to calculate statistics, the chromosomes were provisionally numbered in succession from 1 to 14. Based on enlarged micrographs $(\sim 6000 \times)$ and by means of a digitizer, rectangular coordinates $x_{i}$ and $y_{i}$ of chromosome number $i$ in a cell were recorded for both ends of each chromosome arm and satellite. Centromere positions were calculated as average coordinates of the two sets of coordinates at

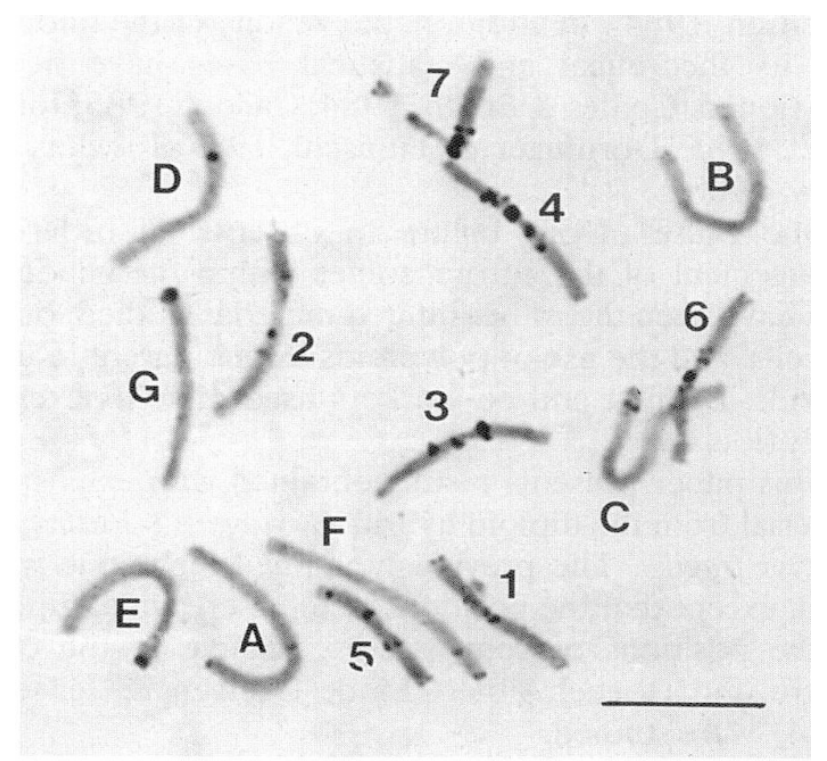

Fig. 1 Giemsa C-banded somatic cell of the intergeneric $H$. vulgare $\times P$. fragilis hybrid $\mathrm{HH} 1432-3 \mathrm{e}$. The $H$. vulgare chromosomes (numbered 1-7) are shorter and more heavily stained than the $P$. fragilis chromosomes (lettered A-G). Bar $=10 \mu \mathrm{m}$. the centromere. The cell centre was determined as the average coordinates of all centromere positions, $x=\operatorname{sum}\left(x_{i}\right) / 14$ and $y=\operatorname{sum}\left(y_{i}\right) / 14$. Combined standard deviations of $x$ and $y$ coordinates at centromere positions,

$S=\left(\operatorname{sum}\left[\left(x_{i}-x\right)^{2}+\left(y_{i}-y\right)^{2}\right] / 2 / 14\right)^{0.5}$,

were used together with the cell centre to transform coordinates both at centromere and telomere positions as

$x_{i}^{\prime}=\left(x_{i}-x\right) / s$ and $y_{i}^{\prime}=\left(y_{i}-y\right) / s$,

in order to obtain standardized measurements and spreading distributions of the chromosomes in the cells. Subsequently, the coordinates of the centromeres were used as in Linde-Laursen \& Jensen (1984). However, the expression used by them was given incorrectly in their paper; the correct one is as reported here. Unless otherwise stated, all distances studied are squared distances in the transformed $x^{\prime}, y^{\prime}$ coordinate system.

\section{Results}

The chromosomes of the Giemsa C-banded metaphases were comparatively long with little overlapping. The cells varied in shape from circular to oblong (Fig. 1). In all cells, each of the seven smaller, more heavily stained $H$. vulgare chromosomes and each of the seven longer, more lightly stained $P$. fragilis chromosomes and their arms were identified by their C-banding patterns (cf. Linde-Laursen \& Bothmer, 1984). Most metaphases had all or most of the $H$. vulgare chromosomes positioned closer to the cell centre than the $P$. fragilis chromosomes; however, in five cells the chromosomes of the two genomes lay side-by-side. In accordance with previous observations, only the nucleolar constrictions of the $H$. vulgare SAT-chromosomes were visible (Linde-Laursen \& Bothmer, 1984). The distribution of the non-squared distances between the cell centre and centromeres is shown in Fig. 2. The distributions appear to be approximately normal and show that the centromeres of the $P$. fragilis chromosomes are generally further from the cell centre than the centromeres of the $H$. vulgare chromosomes. To illustrate the distributions of the centromeres in the squashed metaphase cells, the mean number of centromeres per unit area has been taken as a function of the non-squared distance between the cell centre and the two genomes (Fig. 3). Figure 3 shows, as does Fig. 2, that the centromeres of the $P$. fragilis chromosomes are located further from the cell centre than the centromeres of the $H$. vulgare chromosomes, but Fig. 3 further illustrates that the $P$. fragilis centromeres have a 
Fig. 2 Number of centromeres of $(\square)$ $H$. vulgare and $(\Delta)$ P. fragilis chromosomes from 100 cells of the $H$. vulgare $\times$ P. fragilis hybrid $\mathrm{HH} 1432-3 \mathrm{e}$ as a function of the distances (in standardized units) from the cell centre.
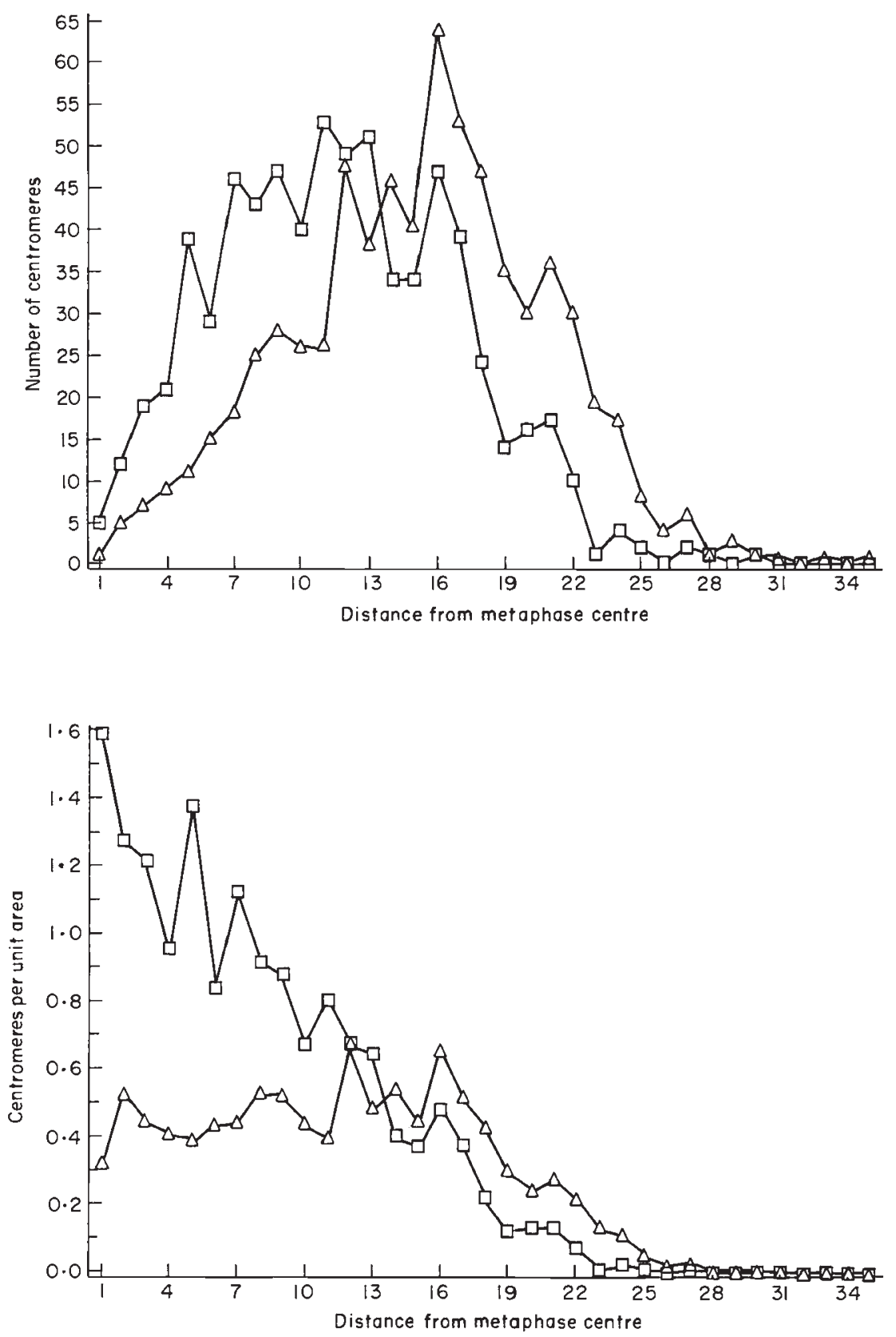

Fig. 3 Number of centromeres per unit area of $(\square) H$. vulgare and $(\Delta) P$. fragilis chromosomes from 100 cells of the $H$. vulgare $\times$ P. fragilis hybrid $\mathrm{HH} 1432-3 \mathrm{e}$ as a function of the distances (in standardized units) from the cell centre. rather even density in a certain area around the cell centre, whereas the density of the $H$. vulgare centromeres is highest at the cell centre and decreases evenly with increasing distance from the centre.

\section{Distances between the cell centre and the individual chromosomes}

The average distances between the cell centre and centromeres and telomeres are given in Table 1. The standard deviations of the average distances to $H$. vulgare and $P$. fragilis centromeres were about 0.2 and 0.3 , respectively, whereas those of the mean distances between the cell centre and telomeres were about 25 per cent higher than of the mean distances to the centromeres. The centromeres of the $P$. fragilis chromosomes are significantly further from the cell centre than the centromeres of the $H$. vulgare chromosomes (Table 1). As the position of the cell centre was calculated by minimizing the distances to the centromeres, it is expected that the telomeres will be located 
Table 1 Mean squared distances between cell centre and centromeres $(\mathrm{C})$ and telomeres $\left(T_{\mathrm{L}}\right.$ and $\left.T_{\mathrm{S}}\right)$ in 100 somatic metaphase cells of the hybrid $H$. vulgare $\times P$. fragilis

\begin{tabular}{llll}
\hline Chromosome* $^{2}$ & $T_{\mathrm{L}}^{\dagger}$ & $C$ & $T_{\mathrm{S}}^{\dagger}$ \\
\hline H. vulgare & & & \\
1 & 1.98 & 1.68 & 2.14 \\
2 & 2.00 & 1.48 & 1.84 \\
3 & 2.01 & 1.54 & 1.87 \\
4 & 1.95 & 1.54 & 1.75 \\
5 & 2.08 & 1.59 & 1.65 \\
6 & 2.01 & 1.48 & 1.76 \\
7 & 1.83 & 1.31 & 1.73 \\
& & & \\
P. fragilis & & & \\
A & 3.32 & 2.60 & 3.02 \\
B & 3.57 & 2.32 & 2.62 \\
C & 3.73 & 2.63 & 2.97 \\
D & 3.49 & 2.44 & 2.84 \\
E & 3.34 & 2.46 & 2.69 \\
F & 3.07 & 2.36 & 2.64 \\
G & 3.15 & 2.58 & 2.89 \\
\hline
\end{tabular}

*For chromosome designations, cf. Linde-Laursen \& Bothmer (1984).

$\dagger T_{\mathrm{L}}$ and $T_{\mathrm{S}}$, telomeres of chromosome arms that have previously been designated long and short, respectively.

further from the cell centre than the centromeres, and also that the telomeres of the long chromosome arms are located further from the cell centre than the telomeres of the short chromosome arms. These expectations were fulfilled except for $H$. vulgare chromosome 6 , the short chromosome arm of which, by addition of the length of the satellite becomes longer than its long arm. The apparent discrepancy for chromosome 1 is due to the designation of the longest arm up to the present as 'the short arm' (J. Jensen \& I. LindeLaursciit, unpublished observations), a designation that continued unchanged.

In each metaphase, the arrangement of the genomes was further studied by: (i) drawing polygons of least diameter including all centromeres of either parent and counting the number of centromeres of the other parent inside the polygon; and (ii) establishing the number of cells in which a circle drawn round the centromeres of one parent did not encompass centromeres of the other parent (cf. Schwarzacher-Robinson et al., 1987). In 44 of the 100 metaphase cells, no $P$. fragilis centromeres lay inside a polygon including all $H$. vulgare centromeres, whereas no more than seven $P$. fragilis polygons contained no $\mathrm{H}$. vulgare centromeres. Both groups comprised the same five cells with the chromosomes in a clear side-by-side arrangement. Furthermore, the total number of $P$. fragilis centro- meres within $H$. vulgare polygons of least diameter was only 99, while $324 \mathrm{H}$. vulgare centromeres lay within $P$. fragilis polygons. Finally, in 20 cells, all $H$. vulgare centromeres could be encompassed by a circle including no $P$. fragilis centromeres. In contrast, no circle encompassed only $P$. fragilis centromeres except in the aforementioned five cells with a side-by-side arrangement of genomes. The three observations agree with respect to a differential disposition of the parental genomes with that of $H$. vulgare closest to the cell centre.

\section{Mean distances between centromeres}

The mean distances between the centromeres of the individual $H$. vulgare chromosomes were in the range from 2.6 to 3.5 length units, between the centromeres of the individual $P$. fragilis chromosomes in the range from 3.9 to 6.1 , and between $P$. fragilis and $H$. vulgare centromeres in the range from 3.5 to 5.2 (Table 2). Thus, the mean distances between the centromeres of $H$. vulgare and $P$. fragilis chromosomes lay between the mean intercentromere distances of the $H$. vulgare and the $P$. fragilis chromosomes, respectively. The distribution of the distances within the groups did not deviate significantly from randomness. The lowest intercentromere distance (2.58 units) was found between the $H$. vulgare SAT-chromosomes 6 and 7, whereas the intercentromere distances of the $P$. fragilis SAT-chromosomes E, F, and G, with their suppressed nucleolar constrictions (Linde-Laursen \& Bothmer, 1984), lay close to the mean of the distances between $P$. fragilis centromeres.

\section{Mean distances between telomeres}

Intertelomere distances might reveal connections between chromosomes not indicated by intercentromere distances (for reference see Avivi \& Feldman, 1980). However, no mean intertelomere distances of either $H$. vulgare (Table 3 ) or $P$. fragilis (not shown) chromosomes indicated that the telomeres of any two chromosomes were significantly closer to each other than they were to the telomeres of other chromosomes. The distances between the telomeres of $H$. vulgare and $P$. fragilis chromosomes were in the ranges from 3.1 to 4.6 and from 3.8 to 6.4 length units, respectively. Because the centering of the cells was based on centromere positions, the mean distance between the telomeres of the short arms of any two chromosomes was, as expected, shorter than the mean distance between the telomeres of the long arms or the mean distances between the telomeres of short and long arms. The mean distance between the two telomeres of each of $H$. 
Table 2 Mean distances in squared standardized units between centromeres of chromosomes in 100 somatic metaphases of the hybrid $H$. vulgare $\times P$. fragilis

\begin{tabular}{|c|c|c|c|c|c|c|c|c|c|c|c|c|c|}
\hline \multirow[b]{2}{*}{ Chromosomes* } & \multicolumn{7}{|c|}{ P. fragilis } & \multicolumn{6}{|c|}{ H. vulgare } \\
\hline & $\mathrm{A}$ & B & $\mathrm{C}$ & $\mathrm{D}$ & $\mathrm{E}$ & $F$ & G & 1 & 2 & 3 & 4 & 5 & 6 \\
\hline \multicolumn{14}{|l|}{ P. fragilis } \\
\hline B & 5.21 & & & & & & & & & & & & \\
\hline C & 5.94 & 4.82 & & & & & & & & & & & \\
\hline D & 5.29 & 4.79 & 6.13 & & & & & & & & & & \\
\hline $\mathrm{E}$ & 5.43 & 4.99 & 5.82 & 5.40 & & & & & & & & & \\
\hline $\mathrm{F}$ & 4.95 & 5.88 & 4.48 & 5.12 & 5.04 & & & & & & & & \\
\hline G & 6.00 & 5.49 & 5.89 & 3.92 & 5.00 & 4.69 & & & & & & & \\
\hline \multicolumn{14}{|l|}{ H. vulgare } \\
\hline 1 & 4.66 & 4.81 & 4.80 & 4.49 & 4.23 & 4.72 & 4.89 & & & & & & \\
\hline 2 & 4.13 & 4.02 & 4.10 & 4.77 & 4.30 & 4.16 & 4.79 & 3.50 & & & & & \\
\hline 3 & 4.48 & 4.05 & 5.22 & 4.62 & 4.25 & 4.38 & 4.76 & 3.28 & 2.95 & & & & \\
\hline 4 & 4.94 & 4.47 & 4.38 & 4.06 & 4.59 & 4.55 & 4.56 & 2.91 & 3.25 & 3.00 & & & \\
\hline 5 & 4.84 & 4.43 & 4.29 & 4.94 & 4.52 & 4.62 & 5.01 & 2.98 & 2.58 & 3.02 & 2.94 & & \\
\hline 6 & 4.71 & 3.49 & 4.75 & 4.64 & 4.23 & 4.65 & 4.90 & 3.03 & 3.25 & 2.60 & 2.92 & 2.92 & \\
\hline 7 & 3.82 & 3.96 & 4.18 & 4.05 & 4.66 & 3.74 & 4.22 & 3.26 & 2.88 & 2.99 & 2.92 & 3.09 & 2.58 \\
\hline
\end{tabular}

*Designations according to Linde-Laursen \& Bothmer (1984).

Table 3 Mean distances in squared standardized units between telomeres of $H$. vulgare chromosomes in 100 somatic metaphases of an $H$. vulgare $\times P$. fragilis hybrid

\begin{tabular}{|c|c|c|c|c|c|c|c|c|c|c|c|c|c|c|}
\hline \multirow[b]{2}{*}{ Chromosome* } & \multicolumn{2}{|l|}{1} & \multicolumn{2}{|l|}{2} & \multicolumn{2}{|l|}{3} & \multicolumn{2}{|l|}{4} & \multicolumn{2}{|l|}{5} & \multicolumn{2}{|l|}{6} & \multicolumn{2}{|l|}{7} \\
\hline & $\mathrm{L}$ & S & $\mathrm{L}$ & $\mathrm{S}$ & $\mathrm{L}$ & $\mathrm{S}$ & L & S & $\mathbf{L}$ & $\mathrm{S}$ & $\mathrm{L}$ & $S$ & $\mathrm{~L}$ & $S$ \\
\hline \multicolumn{15}{|l|}{1} \\
\hline L & & & & & & & & & & & & & & \\
\hline$S$ & 0.93 & & & & & & & & & & & & & \\
\hline \multicolumn{15}{|l|}{2} \\
\hline $\mathrm{L}$ & 4.15 & 4.55 & & & & & & & & & & & & \\
\hline S & 4.05 & 4.37 & 0.96 & & & & & & & & & & & \\
\hline \multicolumn{15}{|l|}{3} \\
\hline $\mathrm{L}$ & 3.95 & 4.53 & 3.83 & 3.76 & & & & & & & & & & \\
\hline$S$ & 3.74 & 4.04 & 3.98 & 3.90 & 0.94 & & & & & & & & & \\
\hline \multicolumn{15}{|l|}{4} \\
\hline $\mathrm{L}$ & 3.41 & 3.43 & 4.42 & 4.10 & 3.83 & 3.59 & & & & & & & & \\
\hline $\mathrm{S}$ & 3.59 & 3.77 & 4.03 & 3.72 & 3.85 & 3.47 & 0.96 & & & & & & & \\
\hline \multicolumn{15}{|l|}{5} \\
\hline L & 3.59 & 3.96 & 3.49 & 3.22 & 3.82 & 3.83 & 3.71 & 3.58 & & & & & & \\
\hline $\mathrm{S}$ & 3.15 & 3.56 & 3.39 & 3.06 & 3.67 & 3.46 & 3.41 & 3.24 & 0.71 & & & & & \\
\hline \multicolumn{15}{|l|}{6} \\
\hline $\mathrm{L}$ & 3.85 & 4.04 & 4.22 & 4.03 & 3.61 & 3.08 & 3.76 & 3.80 & 3.99 & 3.58 & & & & \\
\hline S & 3.55 & 3.82 & 3.74 & 3.80 & 3.75 & 3.37 & 3.70 & 3.51 & 3.61 & 3.26 & 1.27 & & & \\
\hline \multicolumn{15}{|l|}{7} \\
\hline $\mathrm{L}$ & 4.10 & 4.08 & 4.21 & 4.05 & 4.08 & 4.09 & 3.67 & 3.77 & 4.03 & 3.57 & 3.72 & 3.64 & & \\
\hline$S$ & 4.09 & 4.15 & 3.59 & 3.62 & 3.97 & 3.77 & 3.67 & 3.67 & 4.21 & 3.58 & 3.29 & 3.46 & 1.29 & \\
\hline
\end{tabular}

* $\mathrm{L}$ and $\mathrm{S}$ refer to chromosome arms which previously have been designated long and short, respectively. 
vulgare chromosomes 1-4 were very similar, that between the telomeres of chromosome 5 significantly shorter, and those between the telomeres of chromosomes 6 and 7 significantly longer than those between the telomeres of chromosomes 1-4. The mean distances between the telomeres of each of the $P$. fragilis chromosomes (not shown) were generally larger, both between and within chromosomes, than those between the telomeres of $H$. vulgare. The distances between the telomeres of each of the $P$. fragilis SAT-chromosomes $\mathrm{E}, \mathrm{F}$, and $\mathrm{G}$ were of the same order as in chromosomes $\mathrm{A}, \mathrm{B}, \mathrm{C}$, and $\mathrm{D}$. This similarity is probably due to the absence of nucleolar constrictions in the former three chromosomes.

\section{Discussion}

The present study supports the conclusion that parental genomes tend to be differentially disposed in cells of interspecific and intergeneric hybrids at somatic metaphase (for references, see the introduction). A few cells of the present hybrid had the parental genomes in a side-by-side arrangement. This arrangement has also previously been reported for interspecific hybrids with $H$. vulgare as one parent (Bennett, 1984b; Linde-Laursen \& Bothmer, 1984). It has been indicated that this is the normal arrangement in established species (Bennett, 1983, 1984a), but this needs further verification (Bennett, 1987). Thus, Rawlins \& Shaw (1988) found no evidence of a differential distribution of genomes in an extensive study of chromosome positions at anaphase in unsquashed cells of Crepis capillaris using optical tomography. However, as genome arrangements are evidently under genetic control (Bennett, 1984a; Gleba et al., 1987; Schwarzacher-Robinson et al., 1987), there probably exist species-specific differences in this respect. Therefore, it appears likely that sets of chromosomes (genomes) constitute entities of their own (e.g. Avivi \& Feldman, 1980; Heslop-Harrison \& Bennett, 1983b; Bennett, 1984a, 1988). They are probably disposed as two disci in the cells, but in a two-dimensional view they appear to be arranged concentrically and are therefore treated as such.

The theory of an ordered arrangement of the chromosomes within a genome (cf. Avivi \& Feldman, 1980; Ashley \& Pocock, 1981; Bennett, 1982) was unsupported by our study. We did not find any significant evidence of a specific order of the chromosomes of the $H$. vulgare or $P$. fragilis genomes, based either on distances between centromeres or on distances between telomeres. The latter parameter, however, might be the most direct (for references see Ashley, 1979; Avivi \& Feldman, 1980) and therefore also the most sensitive parameter to test the validity of the theory. The present results agree with our previous observations (Linde-Laursen \& Jensen, 1984). Thus, we find it unlikely that support for the theory can be based on observations using light microscopy of normally, although gently squashed metaphases. The absence of an ordered arrangement of the chromosomes in the genome agrees with similar recent observations, e.g. in the plant Crepis capillaris using optical tomography (Rawlins \& Shaw, 1988) and in the grasshopper Caledia captiva using C-banding (Coates \& Smith, 1984). However, genetic differences in this respect apparently exist among organisms.

We found smaller distances among the centromeres of the $H$. vulgare chromosomes than among the centromeres of the $P$. fragilis chromosomes. This has the consequence that the $P$. fragilis chromosomes are further from the cell centre and are more widely distributed than the $H$. vulgare chromosomes in agreement with the observations made in our previous study (LindeLaursen \& Jensen, 1984). The intrachromosomal distances between the telomeres of chromosomes 6 and 7 were relatively long (Table 3 ), probably because the gaps produced by the nucleolar constrictions separated the satellites from the rest of the chromosomes. By adding the lengths of gaps plus satellites to the lengths of the satellited chromosome arms, the short arm of chromosome 7 may become about as long as its long arm, and the length of the short arm of chromosome 6 becomes longer than its long arm (J. Jensen \& I. Linde-Laursen, unpublished observations). Because we have used the minimized distances to the centromeres to locate the cell centre, the distances of the telomeres from the cell centre are expected to be proportional to the length between centromeres and telomeres, i.e. the chromosome arms. A significant deviation from this pattern has been found only for the telomeres of the satellites (Table 1). An attraction to the cell centre, caused by the attachment of the nucleolar organizers to one or more centrically located nucleoli (e.g. Avivi \& Feldman, 1980; Rodman et al., 1980; Bennett, 1984a; Emmerich et al., 1989), may be a probable explanation. Such an attachment may tend to draw chromosomes 6 and 7 closer to the cell centre, and also closer to each other than expected. Indications of such relationships are seen in Tables 1 and 2. A tendency for the chromosomes carrying the nucleolus organizers to be more closely located than expected, based on randomness, has been observed in a number of organisms, e.g. maize and humans (for references see Avivi \& Feldman, 1980; Rodman et al., 1980; Sarma \& Sharma, 1986; Bennett, 1987; Emmerich et al., 1989).

The distribution of distances between centromeres and the cell centre may give the impression that at metaphase the cell centres are more or less devoid of 
centromeres, and thus that the centromeres tend to be arranged in rings at this stage (for references see Heslop-Harrison \& Bennett, 1983c) as is also often seen in cells at late prophase (cf. Bennett, 1984c). The distribution of the centromeres of the parental genomes of our material, according to the mean cell centre distance, gives a similar impression. However, we do not find this relationship if the distance of the centromeres from the cell centre is related to the number of centromeres per square unit (Fig. 3). Although centromere disposition in our material is influenced by the squashing procedure applied, the use of the parameter number of centromeres per square unit (instead of merely the number of centromeres) probably gives a more realistic picture of the distribution of the centromeres within cells at metaphase. One outcome is that the arrangement of the genomes in rings becomes less apparent (cf. Heslop-Harrison \& Bennett, 1983c).

The generally lower density per unit area, and the wider distribution of the $P$. fragilis than of the $H$. vulgare centromeres may be an effect of the less firm attachment of the spindle microtubuli to the centromeres of the former than to the centromeres of the latter species (Finch, 1983; Finch \& Bennett, 1983; Schwarzacher et al., 1984).

The cause of the differential disposition of the parental genomes in the $H$. vulgare $\times P$. fragilis hybrid is possibly the difference between species in the rhythms of chromosome contraction during cell division, i.e. genomic allocycly; this may lead to lagging and loss of the chromosomes of the set contracting belatedly. It has been observed, or suggested, in both somatic and meiotic metaphases of a number of intergeneric hybrids (e.g. Forster \& Dale, 1983; Pohler \& Clauss, 1985, 1988; Schwarzacher-Robinson et al., 1987; Linde-Laursen \& Bothmer, 1989).

It might be argued that measurement of the positions of chromosomes in metaphases only with well-spread chromosomes has given biased estimates. However, because we have worked with relative positions a possible bias will only have accentuated or diluted existing systematic effects.

\section{Acknowledgement}

The skilful technical assistance of Mrs Elly Ibsen is greatly appreciated.

\section{References}

ASHLEY, T. 1979. Specific end-to-end attachment of chromosomes in Ornithogalum virens. J. Cell. Sci., 38, 357-367.
ASHLEY, T. AND POCOCK, N. 1981. A proposed model of chromosomal organization in nuclei at fertilization. Genetica, 55, 161-169.

AVIVI, L. AND FELDMAN, M. 1980. Arrangement of chromosomes in the interphase nucleus of plants. Hum. Genet., 55, 281-295.

BENNETT, M. D. 1982. Nucleotypic basis of the spatial ordering of chromosomes in eukaryotes and the implications of the order for genome evolution and phenotypic variation. In: Dover, G. A. and Flavell, R. B. (eds), Genome Evolution. Academic Press, London, pp. 239-261.

BENNETT, M. D. 1983. The spatial disposition of chromosomes. In: Brandham, P. E. and Bennett, M. D. (eds), Kew Chromosome Conference 1I. Allen \& Unwin, London, pp. 71-79.

BENNETT, M. D. 1984a. Nuclear architecture and its manipulation. In: Gustafson, J. P. (ed.), Gene Manipulation in Plant Improvement. Plenum, New York, pp. 469-502.

BENNETT, M. D. 1984b. Premeiotic events and meiotic chromosome pairing. In: Evans, C. W. and Dickinson, H. G. (eds), Controlling Events in Meiosis. Symp. Soc. Exp. Biol., 38. Company of Biologists, Cambridge, pp. 87-121.

BENNETT, M. D. 1984c. Towards a general model for spatial law and order in nuclear and karyotypic architecture. In: Bennett, M. D., Gropp, A. and Wolf, U. (eds), Chromosomes Today 8. Allen \& Unwin, London, pp. 190-202.

BENNETT, M. D. 1987. Ordered disposition of parental genomes and individual chromosomes in reconstructed plant nuclei, and their implications. Somatic Cell Mol. Genet., 13, 463-466.

BENNETT, M. D. 1988. Parental genome separation in $F_{1}$ hybrids between grass species. In: Brandham, P. E. (ed.), Kew Chromosome Conference III. Her Majesty's Stationery Office, London, pp. 195-208.

BOTHMER, R. VON, JACOBSEN, N., JØRGENSEN, R. B. AND LINDELAURSEN, I. 1984. Haploid barley from the intergeneric cross Hordeum vulgare $\times$ Psathyrostachys fragilis. Euphytica, 33, 363-367.

Callow, R. S. 1985. Comments on Bennett's model of chromosome disposition. Heredity, 54, 171-177.

COATES, D. G. AND SMITH, D. 1984. The spatial distribution of chromosomes in metaphase neuroblast cells from subspecific $F_{1}$ hybrids of the grasshopper Caledia captiva. Chromosoma, 90, 338-348.

DORNINGER, D. AND TIMISCHL, w. 1987. Geometrical constraints on Bennett's predictions of chromosome order. Heredity, 58, 321-325.

EMMERICH, P., LOOS, P., JAUCH, A. et al. 1989. Double in situ hybridization in combination with digital image analysis: a new approach to study interphase chromosome topography. Exp. Cell Res., 181, 126-140.

FINCH, R. A. 1983. Tissue-specific elimination of alternative whole parental genomes in one barley hybrid. Chromosoma, 88, 386-393.

FINCH, R. A. AND BENNETT, M. D. 1981. Spatial separation of mitotic parental genomes in Hordeum $\times$ Secale hybrids. In: Asher, M. J. C., Ellis, R. P., Hayter, A. M. and Whitehouse, R. N. H. (eds), Barley Genetics IV. Edinburgh University Press, Edinburgh, pp. 746-750. 
FINCH, R. A. AND BENNETT, M. D. 1983. The mechanism of somatic chromosome elimination in Hordeum. In: Brandham, P. E. and Bennett, M. D. (eds), Kew Chromosome Conference II. Allen \& Unwin, London, pp. 147-154.

FINCH, R. A., SMITH, J. B. AND BENNETT, M. D. 1981. Hordeum and Secale mitotic genomes lie apart in a hybrid. J. Cell Sci., 52, 391-403.

FORSTER, B. P. AND DALE, J. E. 1983. Effects of parental embryo and endosperm mitotic cycle times on development of hybrids between barley and rye. Ann. Bot., 52, 613-621.

GLEBA, Y. Y., PAROKONNY, A., KOTOV, v., NEGRUTIU, I. AND MOMOT, v. 1987. Spatial separation of parental genomes in hybrids of somatic plant cells. Proc. Natl. Acad. Sci. USA, 84, 3709-3713.

HESLOP-HARRISON, J. S. AND BENNETT, M. D. 1983a. Prediction and analysis of spatial order in haploid chromosome complements. Proc. R. Soc. Lond., B2 18, 211-223.

HESLOP-HARRISON, J. S. AND BENNETT, M. D. 1983b. The spatial order of chromosomes in root-tip metaphases of Aegilops umbellulata. Proc. R. Soc. Lond., B218, 225-239.

HESLOP-HARRISON, J. S. AND BENNETT, M. D. 1983c. The positions of centromeres on the somatic metaphase plate of grasses. J. Cell Sci., 64, 163-177.

HESLOP-HARRISON, J. S. AND BENNETT, M. D. 1984. Chromosome order - possible implications for development. $J$. Embryol. Exp. Morph., 83, (Suppl. no.), 51-73.

JOHN, B., KING, M., SCHWEIZER, D. AND MENDELAK, M. 1985. Equilocality of heterochromatin distribution and heterochromatin heterogeneity in acridid grasshoppers. Chromosoma, 91, 185-200.

LINDE-LAURSEN, I. AND BOTHMER, R. VON. 1984. Somatic cell cytology of the chromosome eliminating, intergeneric hybrid Hordeum vulgare $\times$ Psathyrostachys fragilis. Can. J. Genet. Cytol., 26, 436-444.
LINDE-LAURSEN, I. AND BOTHMER, R. VON. 1989. Allocycly and nucleolar dominance in Hordeum $\times$ Secale amphiploid somatic metaphases. Hereditas, 111, 85-86.

LINDE-LAURSEN, I. AND JENSEN, J. 1984. Separate location of parental chromosomes in squashed metaphases of hybrids between Hordeum vulgare L. and four polyploid, alien species. Hereditas, 100, 67-73.

POHLER, W. AND CLAUSS, E. 1985. Genomallozyklie verursacht zytologische Störungen bei Hordeum-Secale-Bastarden. Biol. Zbl., 104, 145-154.

POHLER, W. AND ClAUSS, E. 1988. Genomic allocycly - A hypothesis originally developed for triticale proved valid in Hordeum $\times$ Secale hybrids. Tag.-Ber. Akad. Landwirtsch.Wiss. DDR, Berlin, 266, 105-114.

RAWLINS, D. J. AND SHAW, P. J. 1988. Three-dimensional organization of chromosomes of Crepis capillaris by optical tomography. J. Cell Sci., 91, 401-414.

RODMAN, T. C., FLEHINGER, B. J. AND ROHLF, F. J. 1980. Metaphase chromosome associations: colcemid distorts the pattern. Cytogenet. Cell. Genet., 27, 98-110.

SARMA, J. S. P. AND SHARMA, A. K. 1986. Nonrandom arrangement of satellited chromosomes in maize and its implication. Nucleus, 29, 39-44.

SCHWARZACHER, T., FINCH, R. A. AND BENNETT, M. D. 1984. Genome elimination in Hordeum hybrids. In: Bennett, $\mathrm{M}$ D., Gropp, A. and Wolf, U. (eds), Chromosomes Today 8. Allen \& Unwin, London, p. 339.

SCHWARZACHER-ROBINSON, T., FINCH, R. A., SMITH, J. B. AND BENNETT, M. D. 1987. Genotypic control of centromere positions of parental genomes in Hordeum $\times$ Secale hybrid metaphases. J. Cell. Sci., 87, 291-304.

ZELESCO, P. A. AND GRAVES, J. A. M. 1988. Chromosome segregation from cell hybrids. IV. Movement and position of segregant set chromosomes in early-phase interspecific cell hybrids. J. Cell. Sci., 89, 49-56. 